\title{
Disruption of Antigen-induced Inflammatory Responses in CD40 Ligand Knockout Mice
}

\author{
Xue-Feng Lei, Yuichi Ohkawara, Martin R. Stämpfli, Claudio Mastruzzo, Robert A. Marr, Denis Snider, Zhou Xing, \\ and Manel Jordana \\ Department of Pathology, Immunology and Infection Programme, McMaster University, Hamilton, Ontario, Canada L8N $3 Z 5$
}

\begin{abstract}
The objective of this study was to investigate the contribution of the interaction between CD40 and its ligand (CD40L) to antigen-induced airways inflammatory responses. To this end, we used a model involving ovalbumin (OVA) sensitization followed by OVA aerosol challenge in CD40L knockout (KO) mice. OVA-specific IgE and $\mathrm{IgG}_{1}$ were detected in the serum of the sensitized control, but not in CD40L-KO mice. After antigen challenge, sensitized control mice developed airway inflammation that was primarily eosinophilic. This inflammatory response was dramatically reduced in CD40L-KO mice. In contrast, similar numbers of eosinophils were observed in both the bone marrow and the peripheral blood in the sensitized controls and mutant strains after antigen challenge. To investigate the mechanisms underlying these findings, we examined levels of the cytokines IL-5, IL-4, and TNF $\alpha$ in both bronchoalveolar lavage (BAL) and serum. Similar levels of IL-5 were detected in BAL and serum of control and CD40L-KO mice; however, negligible levels of IL-4 in BAL and serum and of TNF $\alpha$ in BAL were detected in CD40L-KO mice when compared with control mice. Furthermore, we demonstrated that endothelial cell expression of vascular cell adhesion molecule 1 in OVA-sensitized and -challenged CD40L-KO mice was, as detected by immunohistochemistry, markedly decreased compared with that observed in similarly treated control mice. In addition, we locally overexpressed IL-4 and TNF $\alpha$ by using an adenoviral (Ad)-mediated gene transfer approach. Intranasal administration of either $\mathrm{Ad} / \mathrm{TNF} \alpha$ or Ad/IL-4 into OVA-sensitized and -challenged CD40L-KO mice did not reconstitute airway eosinophilia. However, concurrent administration of Ad/TNF $\alpha$ and Ad/IL-4 upregulated endothelial expression of vascular cell adhesion molecule 1, and resulted in full reconstitution of the inflammatory response in the airways. Together, these findings demonstrate the importance of the CD40-CD40L costimulatory pathway in the full expression of the inflammatory
\end{abstract}

Address correspondence to Manel Jordana M.D., Ph.D., McMaster University, Health Sciences Centre, Room 4H21, Department of Pathology, 1200 Main Street West, Hamilton, Ontario, Canada L8N 3Z5. Phone: 905-525-9140 ext. 22473; FAX: 905-522-6750; E-mail: jordanam@fhs.csu.mcmaster.ca

Received for publication 5 September 1997 and accepted in revised form 21 January 1998.

J. Clin. Invest.

(C) The American Society for Clinical Investigation, Inc. 0021-9738/98/03/1342/12 \$2.00

Volume 101, Number 6, March 1998, 1342-1353

http://www.jci.org response in the airways. (J. Clin. Invest. 1998. 101:13421353.) Key words: CD40 - CD40L • airways inflammation • IL-5, IL-4 • TNF $\alpha$

\section{Introduction}

A central hallmark of the pathogenesis of asthma is the development of a certain type of immune inflammatory response that includes both cellular and humoral components (1-3). While a defining feature of asthmatic bronchial inflammation is peripheral blood and tissue eosinophilia, there is increasing evidence that lymphocytes, particularly $\mathrm{T}$ cells, are the primary initiators of the asthmatic inflammatory reaction $(1,4)$. With respect to humoral components, it is apparent that $\mathrm{IgE}$ is critical for generating allergic responses, and hence may play an important role in asthmatic bronchial inflammation (5). The ability to reproduce these cardinal features of asthma in murine models involving sensitization and aerosol challenge with ovalbumin (OVA; references 6-10) ${ }^{1}$ suggests that studies using these experimental models may yield knowledge relevant to the basic pathogenesis of asthmatic inflammation.

The CD40-CD40L interaction plays a well-defined role in humoral immune responses. The cognate interaction of CD40L (also referred to as gp39) expressed on $\mathrm{CD}^{+} \mathrm{T}$ lymphocytes with CD40 expressed on B cells is, together with IL-4 (12), essential for the $\operatorname{IgE}$ isotype switch (11). However, CD40 and CD40L are also expressed on a number of other cell types including monocytes, dendritic cells, eosinophils, and endothelial cells $(11,13-16)$, suggesting broader involvement of this receptor-ligand interaction in immune responses. In this regard, three recent studies investigating immune inflammatory responses to parasites in CD40- (17) and CD40L-knockout (KO) mice $(18,19)$ have established the importance of the CD40CD40L signaling system in cellular immune responses as well.

In this study, we wished to investigate the involvement of the CD40-CD40L interaction in a murine model of allergic airways inflammation. To this end, we used CD40L-KO mice that were first sensitized, and then aerosol-challenged with OVA. We found that CD40L-KO and control littermates developed a similar bone marrow eosinopoietic response consistent with similarly increased levels of IL-5 in both the serum and BAL. However, the inflammatory response of CD40L$\mathrm{KO}$ mice in both the BAL and the lung/airways was markedly abrogated. In contrast to control littermates, CD40L-KO mice had undetectable levels of OVA-specific $\mathrm{IgE}$ and $\mathrm{IgG}_{1}$ in the serum, and negligible levels of IL-4 in both BAL and serum and TNF $\alpha$ in BAL. In addition, endothelial cell expression of VCAM-1 was markedly decreased in the mutant strain after aerosol challenge. Local replacement of both TNF $\alpha$ and IL-4

1. Abbreviations used in this paper: $\mathrm{KO}$, knockout; OVA, ovalbumin. 
by means of an adenoviral-mediated gene transfer approach resulted in upregulation of VCAM-1 expression and full reconstitution of the inflammatory response in the airways. These findings demonstrate the importance of CD40-CD40L interactions in the development of antigen-induced immuneinflammatory responses in the airways.

\section{Methods}

Animals. Female CD40L-KO (6-8 wk, B6, 129-Cd401 ${ }^{\mathrm{tm} 1 \mathrm{Imx}}$ ) and control mice were purchased from The Jackson Laboratory (Bar Harbor, $\mathrm{ME}$ ) and were maintained in Level B housing conditions in a 12-h light-dark cycle. Level B is an access-restricted area; all cages, food, and bedding are autoclaved, and all mice manipulations are carried out in a laminar flow hood by gloved and masked personnel only. All the experiments described in this manuscript were approved by the Animal Research Ethics Board of McMaster University.

Sensitization and antigen challenge protocol. The sensitization and challenge protocols we followed have been described previously (6). In brief, mice were sensitized at days 0 and 5 of the protocol by an intraperitoneal injection of $0.5 \mathrm{ml}$ aluminum hydroxide-precipitated antigen containing $8 \mu \mathrm{g}$ ovalbumin (Sigma Chemical Co., St. Louis, $\mathrm{MO}$ ) adsorbed overnight at $4^{\circ} \mathrm{C}$ to $4 \mathrm{mg}$ of aluminium hydroxide (Aldrich Chemical Co., Milwaukee, WI) in PBS. $12 \mathrm{~d}$ later, mice were placed in a Plexiglas chamber $(10 \mathrm{~cm} \times 15 \mathrm{~cm} \times 25 \mathrm{~cm})$ and exposed to aerosolized OVA $(5 \mathrm{mg} / \mathrm{ml}$ in $0.9 \%$ saline $)$ for $1 \mathrm{~h}$ on two occasions $4 \mathrm{~h}$ apart. The aerosolized OVA was produced by a Bennet nebulizer at a flow rate of 10 liter/min.

Collection and measurement of specimens. At various times during sensitization and after antigen challenge, mice were killed, and broncho-alveolar lavage (BAL) fluid, blood, bone marrow, and lung tissue were collected. To collect BAL fluid, the lungs were dissected and the trachea was cannulated with a polyethylene tube (Becton Dickinson, Sparks, MD). The lungs were lavaged twice with PBS $(0.25,0.20 \mathrm{ml}$ each time $)$, and $\sim 0.4 \mathrm{ml}$ of the instilled fluid was consistently recovered. Total cell numbers were counted with a hemocytometer. After centrifugation, supernatants were stored at $-70^{\circ} \mathrm{C}$ for cytokine measurements by ELISA, and cell pellets were used to prepare cytospins. Blood samples were obtained by retroorbital bleeding, and blood smears were prepared. Serum was obtained by centrifugation after incubating blood for $30 \mathrm{~min}$ at $37^{\circ} \mathrm{C}$. Total white cell number in peripheral blood was counted after red blood cell lysis. Bone marrow cells were collected from femoral bone according to a previously described procedure (6). In brief, one femur from each mouse was flushed with HBSS (Gibco Laboratories, Grand Island, NY), and a single-cell suspension was obtained after red blood cell lysis using distilled water. The cells were washed twice in HBSS and resuspended in $2 \mathrm{ml}$ of RPMI 1640 (Gibco Laboratories) containing $2 \mathrm{mM}$ glutamine, $10 \% \mathrm{FBS}, 100 \mathrm{U} / \mathrm{ml}$ of penicillin, and $100 \mu \mathrm{g} / \mathrm{ml}$ of streptomycin, and the total cell number was counted. Smears of BAL cells and bone marrow cells were prepared by cytocentrifugation (Shandon Inc., Pittsburgh, PA) at $300 \mathrm{rpm}$ for $2 \mathrm{~min}$. All smears were stained with Diff-Quik stain (Baxter, McGraw Park, IL). Differential cell counts in BAL were determined from at least 500 leukocytes using standard hemocytological criteria to classify the cells as either neutrophils, eosinophils, lymphocytes, or other mononuclear leukocytes (macrophages and monocytes). The lung tissue was fixed with periodate-lysin-paraformaldehyde solution, and was embedded in paraffin. $3-\mu \mathrm{m}$-thick sections were stained with hematoxylin and eosin (H\&E).

Spleen cell culture. Spleens from either mock or OVA-sensitized mice were harvested $5 \mathrm{~d}$ after the second intraperitoneal injection, and single-cell suspensions were prepared. Spleens were injected from both ends with $1 \mathrm{ml} 100 \mathrm{U} / \mathrm{ml}$ collagenase II (Worthington Biochemical Corp., Freehold, NJ), cut into pieces, and incubated in $1 \mathrm{ml}$ $400 \mathrm{U} / \mathrm{ml}$ collagenase for $7 \mathrm{~min}$ at $37^{\circ} \mathrm{C}$. Subsequently, spleens were ground between frosted slides and filtered through a Nylon mesh
(HD 352; B\&SH Thompson \& Co., Scarborough, Ontario). Red blood cells were lysed with ACK buffer. Total spleen cells were cultured at $8 \times 10^{5}$ cells/well in flat-bottomed 96-well plates in RPMI 1640 (Gibco Laboratories) supplemented with $2 \mathrm{mM}$ glutamine, $10 \%$ FBS, $100 \mathrm{U} / \mathrm{ml}$ penicillin and $100 \mu \mathrm{g} / \mathrm{ml}$ streptomycin in the presence or absence of $200 \mu \mathrm{g} / \mathrm{ml}$ OVA. Cell proliferation was assessed by $\left[{ }^{3} \mathrm{H}\right]$ thymidine incorporation $[1 \mu \mathrm{Ci} /$ well $]$ at day 3 . Results are expressed as stimulation index (OVA-induced proliferation divided by background proliferation). Cell supernatants for IL-4 and IL-5 cytokine analysis were harvested at day 5 and stored at $-20^{\circ} \mathrm{C}$.

Cytokine assay. ELISA kits for mouse TNF $\alpha$, IL-5, and IL-4 were purchased from Amersham International (Buckinghamshire, United Kingdom). The sensitivity of detection is $5 \mathrm{pg} / \mathrm{ml}$ for all three cytokines.

$\operatorname{IgE}$ measurement. Levels of OVA-specific mouse $\operatorname{IgE}$ were detected using a previously described antigen-capture ELISA method (20). In brief, ELISA plates (Maxisorb F96; Nalge Nunc International, Naperville, IL) were incubated with $50 \mu \mathrm{l}$ monoclonal antimouse IgE (MoME-3; Université de Louvain, Belgium) at a concentration of $5 \mu \mathrm{g} / \mathrm{ml}$ in $0.2 \mathrm{M}$ borate-buffered saline ( $\mathrm{pH} 8.3$ ) for $16-18 \mathrm{~h}$ at $4^{\circ} \mathrm{C}$. After discarding the coating solution, the remaining binding sites on the plate were blocked with $1 \% \mathrm{wt} / \mathrm{vol}$ BSA in PBS for $2 \mathrm{~h}$ at room temperature. The plates were washed, and $50 \mu \mathrm{l}$ mouse serum diluted between 1:5 and 1:40 in PBS containing $0.3 \% \mathrm{wt} / \mathrm{vol}$ BSA was added to each well. Then, the plates were incubated for $16-18 \mathrm{~h}$ at $4^{\circ} \mathrm{C}$. After extensive washing, $50 \mu \mathrm{l}$ of a $1 \mu \mathrm{g} / \mathrm{ml}$ solution of biotin-conjugated OVA in $0.3 \% \mathrm{wt} / \mathrm{vol} \mathrm{BSA} / \mathrm{PBS}$ was placed in each well, and the plates were incubated for $2 \mathrm{~h}$ at room temperature. After further washing, the plates were incubated with a 1:1,000 dilution of alkalinephosphatase-conjugated streptavidin (Intermedico, Mississauga, Ontario), and the plate-bound alkaline phosphatase activity was detected using alkaline phosphatase substrate tablets (Sigma Chemical Co.) and assessed using an ELISA reader at $492 \mathrm{~nm}$. Each sample was examined in duplicate, and the mean values recorded. A standard curve for each assay was obtained using biotin-conjugated $\operatorname{IgE}$, and results were expressed as $\mathrm{ng}$ of specific IgE per $\mathrm{ml}$ of serum relative to the standard curve.

$I g G_{1}$ measurement. OVA-specific $\mathrm{IgG}_{1}$ was determined using a standard ELISA protocol. In brief, F96 Maxisorb NUNC-Immunoplates (Gibco Laboratories) were coated with $100 \mu \mathrm{l}$ OVA $(5 \mu \mathrm{g} / \mathrm{ml}$; Sigma Chemical Co.) in borate-buffered saline ( $\mathrm{pH} 8.6 ; 0.15 \mathrm{M} \mathrm{NaCl}$, $0.05 \mathrm{M}$ boric acid, $0.04 \mathrm{M}$ Borax, and $0.02 \% \mathrm{NaN}_{3}$ ) for $1 \mathrm{~h}$ at $37^{\circ} \mathrm{C}$. Subsequently, the coating solution was discarded, and the plates were blocked with $150 \mu \mathrm{l} \mathrm{BSA} \mathrm{(10} \mathrm{mg/ml;} \mathrm{Sigma} \mathrm{Chemical} \mathrm{Co.} \mathrm{)} \mathrm{in} \mathrm{PBS} \mathrm{for}$ $1 \mathrm{~h}$ at $37^{\circ} \mathrm{C}$. After discarding the blocking solution, serial dilutions of serum samples were incubated for $1 \mathrm{~h}$ at $37^{\circ} \mathrm{C}$. The plates were washed with PBS-Tween and incubated with $100 \mu$ l of 1:5,000 diluted alkaline phosphatase (Sigma Chemical Co.) for $1 \mathrm{~h}$ at $37^{\circ} \mathrm{C}$. After washing, the plates were developed with $1 \mathrm{mg} / \mathrm{ml}$ of p-nitrophenyl phosphate and read at $405 \mathrm{~nm}$. Units of OVA-specific $\operatorname{IgG}_{1}$ were determined by comparison to a standard serum.

Delivery of adenoviral constructs into the airways. To overexpress IL-4 and TNF $\alpha$ in the airways compartment, we elected to use adenoviral vectors expressing either the IL- 4 or the $\mathrm{TNF} \alpha$ transgene, whose construction has been previously reported $(21,22)$. In brief, the shuttle plasmid pCAIL-4p was generated by insertion of the cDNA for murine IL-4 into the plasmid pCA13, which contains the human cytomegalovirus immediate early (HCMV IE) promoter and the SV40 polyadenylation signals. The shuttle plasmid pmTNF-wt was generated by inserting the cDNA for murine TNF $\alpha$ into the plasmid pMH4, which contains MCMV promoter and the SV40 polyadenylation signals. The recombinant viruses AdCAIL-4 and AdmTNFwt were obtained by cotransfection of 293 cells with shuttle plasmids pCAIL-4 or pmTNF-wt and pBGH10 and homologous recombination between overlapping sequences. Since these plasmids lack the E1 sequences necessary for viral replication, recombinant viruses derived from them are replication-deficient in cells other than 293s. Henceforth, these constructs will be referred to as Ad/IL-4 and Ad/ 
TNF $\alpha$. Adl 70-3, which has a deletion in E1 and a deletion/substitution in E3, was used as a negative control vector (23).

For intranasal delivery, Ad/IL-4, Ad/TNF $\alpha$, and the control vector Adl 70-3 were diluted to $0.01 \times 10^{9} \mathrm{pfu}$ in a total volume of $30 \mu \mathrm{l}$. This volume was divided into two halves that were slowly applied into the nasal orifices of anaesthesized mice that were manually held in an upright position. In experiments involving OVA sensitization and challenge, adenoviral constructs were delivered to sensitized mice $4 \mathrm{~d}$ before aerosolized OVA challenge.

VCAM-1 immunohistochemistry. Tissues were processed as previously described (24). In brief, mouse lung tissues were fixed in periodate-L-lysine paraformaldehyde and dehydrated through a sucrose gradient. The tissues were embedded with Tissue-Tec OCT compound (Miles Laboratories) in liquid nitrogen and stored at $-70^{\circ} \mathrm{C}$. Serial cryostat sections (6- $\mu \mathrm{m}$ thick) were cut onto slides coated with 3 aminopropyltrietoxysilane (Sigma Chemical Co.). To remove OCT compound, slides were rinsed in PBS for 5 min three times. After blocking nonspecific protein binding with $1 \%$ BSA (Sigma Chemical Co.) in PBS, sections were incubated with appropriate dilutions of specific primary antibodies overnight at $4^{\circ} \mathrm{C}$. The antibodies used were rat monoclonal anti-mouse VCAM-1 (PharMingen, San Diego, CA) and rat $\operatorname{IgG}_{2}$ (PharMingen) as a negative control. Slides were washed with PBS and incubated with rabbit anti-rat IgG (DAKO Corp., Carpinteria, CA) for $60 \mathrm{~min}$ at room temperature, and further incubated with rat alkaline phosphatase antialkaline phosphatase complex (DAKO Corp.) for $60 \mathrm{~min}$ after washing with PBS. Alkaline phosphatase substrate in the presence of levamisole (Vector Laboratories, Inc., Burlingame, CA), at a concentration of $5 \mathrm{mM}$ to block endogenous alkaline phosphatase, was used for signal detection (New Fuchsin Substrate System; DAKO Corp.). Counterstaining was performed with Mayer's hematoxylin (Sigma Chemical Co.) for $2 \mathrm{~min}$, and was mounted with GVA-mount (Zymed Laboratories, Inc., South San Francisco, CA).

Assessment of VCAM-1 expression. Tissue sections were analyzed with a Zeiss photomicroscope. VCAM-1 staining was evaluated by performing a systematic sampling of fields within a lung section combined with a grading system described previously (25). The intensity of positive endothelial cell labeling was scored as weak, moderate, and intense within each microscopic field by using a calibrated $10 \times$ eyepiece graticule and a $20 \times$ objective. The size of the section determined the number of fields sampled per slide. VCAM-1 expression of vascular endothelium was assessed by a semiquantitative scoring method that included the number of positively stained vessels as well as the staining intensity: grade 0 , no visible staining; grade 1 , a few vessels with weak staining; grade 2, moderate staining of a few vessels with weak staining of surrounding vessels; grade 3 , intense staining of most vessels in specific regions with weak or moderate staining of surrounding vessels; and grade 4, intense staining of most vessels. Samples were evaluated blindly in random order.

Data analysis. Data were expressed as mean \pm SEM. Wherever suitable, interpretation of results included ANOVA. Differences were considered statistically significant when $P<0.05$.

\section{Results and Discussion}

Renshaw et al. documented that CD40L-KO mice develop normally and show no apparent health abnormalities (26). These mice have normal numbers of $\mathrm{B}$ and $\mathrm{T}$ cells, but they have significantly lower basal levels of $\operatorname{IgA}, \operatorname{IgG}_{1}$, and $\operatorname{IgG}_{2 b}$ as well as undetectable levels of $\mathrm{IgE}$ in the serum compared with control littermates. Furthermore, they are unable to mount a T cell-dependent secondary humoral response for all isotypes with the exception of $\operatorname{IgM}(26,27)$.

$\operatorname{IgE}$ and $\operatorname{Ig} G_{1}$ content in serum. As previously indicated, the interaction of CD40 with its ligand is, together with IL-4, essential for the $\operatorname{IgE}$ isotype switch. This response is of critical
Table I. OVA-specific IgE and IgG Levels in Serum* $^{*}$

\begin{tabular}{lcccccc}
\hline & \multicolumn{2}{c}{ OVA-specific IgE } & & \multicolumn{2}{c}{ OVA-specific $\mathrm{IgG}_{1}$} \\
\cline { 2 - 3 } \cline { 6 - 7 } & CD40L-KO & $\begin{array}{c}\text { Control } \\
\text { mice }\end{array}$ & & & CD40L-KO & $\begin{array}{c}\text { Control } \\
\text { mice }\end{array}$ \\
\hline Naive & $n g / m l$ & $n g / m l$ & & $U / m l$ & $U / m l$ \\
Sensitized & 0 & 0 & & $<5$ & $<5$ \\
Sensitized/challenged & $0.3 \pm 0.1$ & $45.1 \pm 0.2$ & & $<5$ & $6497 \pm 1800$ \\
& & & & & & \\
\hline
\end{tabular}

*Values represent $\mathrm{m} \pm \mathrm{SEM}(n=4-8)$. Serum samples from sensitized/ challenged mice were obtained $6 \mathrm{~h}$ after the aerosol challenge.

importance to the activation of resident tissue cells bearing IgE receptors (FcRI or FcRII) such as mast cells, monocytes, or dendritic cells that, upon subsequent antigen cross-linking, will release a variety of inflammatory mediators. It was thus necessary to verify humoral responses in our experimental system. As shown in Table I, whereas $\mathrm{IgE}$ and $\mathrm{IgG}_{1}$ responses were readily measured in control mice, $\mathrm{IgE}$ and $\mathrm{IgG}_{1}$ serum levels were virtually undetectable in CD40L-KO mice in accordance with previous findings (26).

Cellular changes in BAL and lung of sensitized and challenged mice. We have previously shown that intraperitoneal OVA sensitization per se does not significantly change the cellular profile in the BAL as compared with naive (unsensitized) mice (6). It is also well-established that aerosol antigen challenge in sensitized mice elicits an airways inflammatory response that can be detected in both BAL and peribronchial areas (6-10). Fig. 1 shows the changes in BAL cells in CD40L-KO mice and control littermates at 6,24 , and $72 \mathrm{~h}$ after aerosol challenge. Pronounced increases in the number of monocyte/ macrophages, lymphocytes, neutrophils, and eosinophils were observed in sensitized control mice after challenge. In agreement with our previous data, this inflammatory response was maximal at day 3 after challenge, with the exception of neutrophils, which increased in number at as early as $3 \mathrm{~h}$, peaked at $24 \mathrm{~h}$, and had declined $72 \mathrm{~h}$ after challenge. In contrast, the changes in inflammatory cells observed in the BAL of sensitized CD40L-KO mice after challenge were significantly smaller. With respect to mononuclear cells, monocyte/macrophages and lymphocytes were reduced by $\sim 60$ and $80 \%$, respectively, in CD40L-KO mice compared with control littermates. Regarding granulocytes, the reductions were $>60 \%$ and $>90 \%$ for eosinophils and neutrophils, respectively.

Histological evaluation of the lung/airways confirmed these findings. Fig. 2 ( $a$ and $b$ ) illustrates the predominantly eosinophilic nature of the inflammatory infiltrate in sensitized control mice observed $3 \mathrm{~d}$ after antigen challenge. Fig. 2 ( $c$ and $d$ ) shows histology of tissues also obtained $3 \mathrm{~d}$ after aerosol challenge at a low magnification to provide an overall impression of the extent of the inflammatory response, showing marked differences between CD40L-KO and control littermate mice. These observations, together with the BAL findings, demonstrate that a perturbed CD40-CD40L interaction has a major impact on the development of antigen-induced inflammatory responses in the airways.

Cellular changes in peripheral blood and bone marrow. The influx of inflammatory cells into the tissue after challenge 

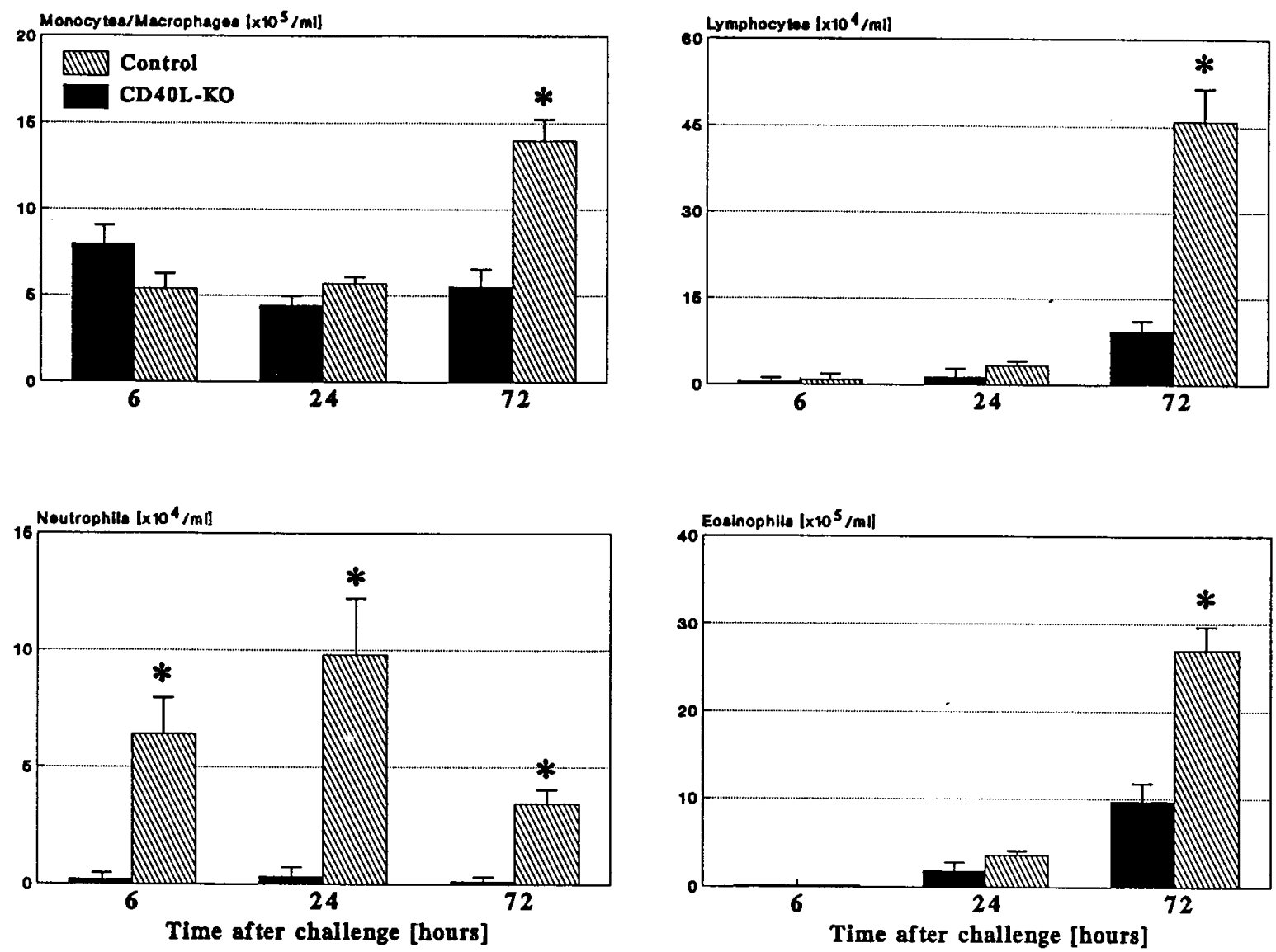

Figure 1. Cellular changes in the BAL in OVA-sensitized mice subjected to an OVA aerosol challenge. Data represent mean \pm SEM $(n=$ 4-8 per point). ${ }^{*} P \leq 0.05$ between CD40L-KO and control littermate mice.

is partly related to the content of such cells in the peripheral circulation which is, in turn, dependent on the hemopoietic response in the bone marrow (6). Table II shows the total cell and differential count of naive CD40L-KO and control littermate mice. No significant differences were observed in peripheral cell counts between the two strains, with the exception of neutrophils whose population was significantly smaller in CD40L-KO mice. An increase in the absolute number of both eosinophils and neutrophils after sensitization and immediately before challenge was observed in both strains. Fig. 3 shows cellular changes in the bone marrow at day 3 after challenge. Based on our previous documentation, this is the time point of maximal response in the bone marrow after aerosol challenge (6). The total cell number as well as the number of mature granulocytes, neutrophils, and eosinophils significantly increased compared with values in naive mice, but no significant differences were observed between CD40L-KO and control mice. Thus, these findings reveal an interesting paradox: while CD40L-KO mice appear to have an intact hemopoietic capability and similar numbers of mononuclear cells and granulocytes in peripheral blood just before antigen challenge compared with control littermates, the inflammatory response observed in both BAL and tissue is markedly reduced in the CD40L-deficient strain. This result suggests a defect in recruitment of blood-borne inflammatory cells into the tissue in CD40L-KO mice.
Hogan et al. (28) have recently reported that sensitized CD40 KO mice have peripheral blood and airway eosinophilia after challenge that are similar to those observed in wild-type control mice. Thus, there is agreement that the CD40-CD40L pathway is not required to generate eosinophilia, at least in peripheral blood, and, as we show here, in the bone marrow. There is an apparent discrepancy with respect to the requirement of this pathway for recruitment of eosinophils into the tissue. However, it is critical to note that the experimental protocol of sensitization and challenge used by Hogan et al. is markedly different than the one we used here, in that mice were exposed to greater concentrations of OVA, and subjected to many repeated aerosolizations. As a result, the histopathological process caused by the Hogan protocol is remarkably different and much more severe than that caused by our protocol. This process includes intense and widespread inflammation, not only of the airways, but also of the parenchyma involving alveolitis, gross structural alterations, microvascular leakage, mucosal edema, and the presence of particulate exudates in the airways lumina and alveolar septa. We suggest that, under these conditions, the fine immunological mechanisms regulating inflammatory cell recruitment are overwhelmed and overridden by the intense lung (airway and parenchyma) damage.

$I L-5, I L-4$, and $T N F \alpha$ content in serum and BAL. Considerable evidence supports the notion that these cytokines play im- 

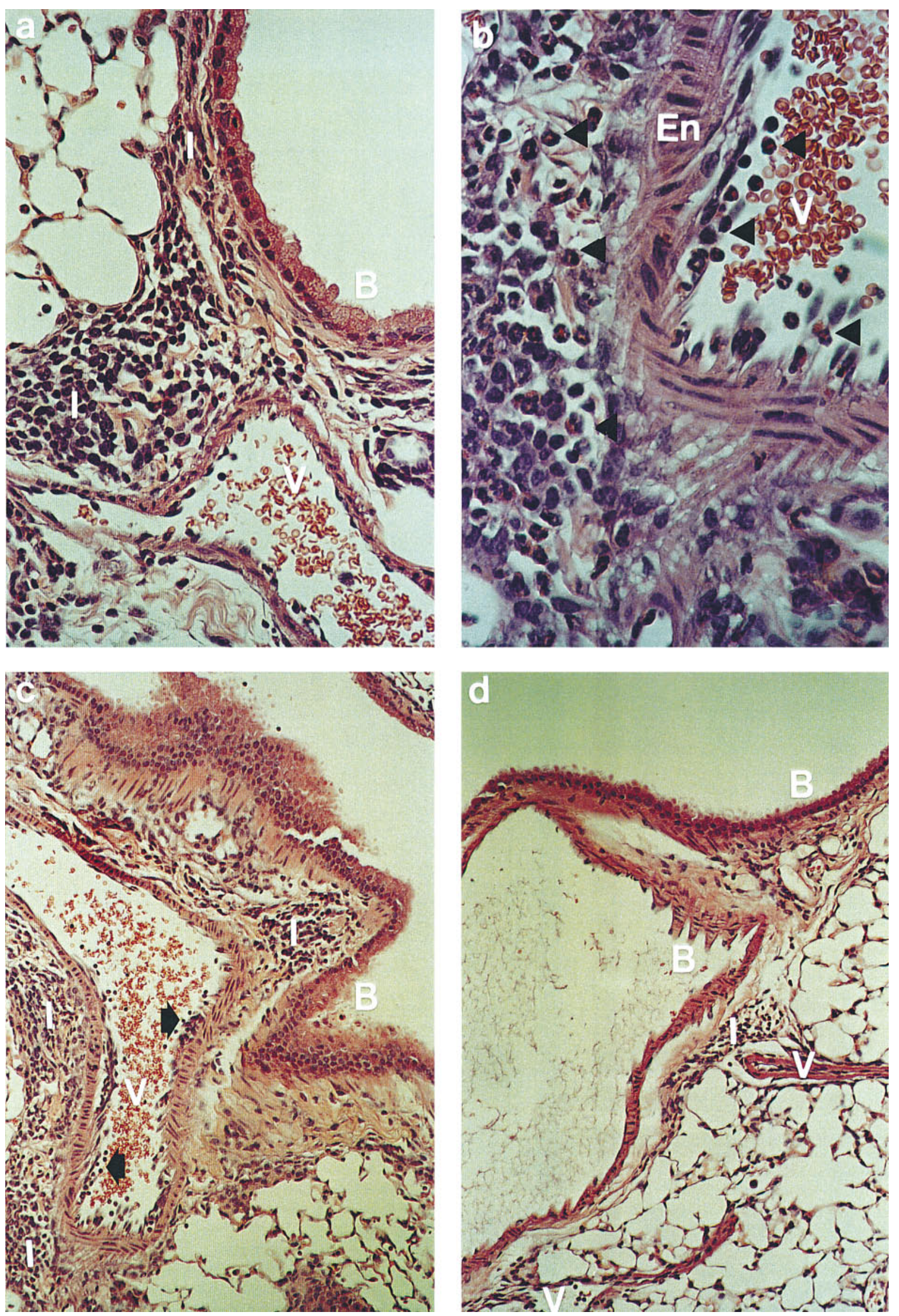

Figure 2. Light photomicrograph of paraffin-embedded sections of lung tissues stained with H\&E obtained from sensitized control littermate $(a-c)$ and CD40L-KO $(d)$ mice at day 3 after OVA aerosol challenge. $V$, Vascular compartment; $B$, bronchi; $I$, areas of inflammation; En, endothelium. Triangles in $b$ indicate eosinophils within and outside the vascular space; arrows in $c$ illustrate blood-borne cells in close proximity to the vascular endothelium. (a) 400×; (b) 640×; ( $c$ and $d$ ) 200×. 
Table II. Changes in Peripheral Blood Cells of Naive and Sensitized Mice*

\begin{tabular}{|c|c|c|c|c|c|c|c|c|c|c|}
\hline & \multicolumn{5}{|c|}{ CD40L-KO } & \multicolumn{5}{|c|}{ Control } \\
\hline & WBC & Mo & Ly & Neu & Eos & WBC & Mo & Ly & Neu & Eos \\
\hline & $10^{3} / \mathrm{ml}$ & $10^{3} / \mathrm{ml}$ & $10^{3} / \mathrm{ml}$ & $10^{3} / \mathrm{ml}$ & $10^{3} / \mathrm{ml}$ & $10^{3} / \mathrm{ml}$ & $10^{3} / \mathrm{ml}$ & $10^{3} / \mathrm{ml}$ & $10^{3} / \mathrm{ml}$ & $10^{3} / \mathrm{ml}$ \\
\hline Naive & $\begin{array}{c}7097.4 \pm \\
667.5\end{array}$ & $\begin{array}{c}226.9 \pm \\
40.3\end{array}$ & $\begin{array}{c}6262.33 \pm \\
558.4\end{array}$ & $\begin{array}{c}334.2 \pm \\
48.0\end{array}$ & $\begin{array}{c}269.0 \pm \\
81.3\end{array}$ & $\begin{array}{c}6809.3 \pm \\
699.3\end{array}$ & $\begin{array}{c}387.1 \pm \\
87.5\end{array}$ & $\begin{array}{c}5568.2 \pm \\
663.3\end{array}$ & $\begin{array}{c}580.9 \pm \\
53.7^{\ddagger}\end{array}$ & $\begin{array}{c}273.1 \pm \\
53.5\end{array}$ \\
\hline Sensitized $^{\S}$ & $\begin{array}{l}8275.3 \pm \\
2106.1\end{array}$ & $\begin{array}{c}340.2 \pm \\
56.3\end{array}$ & $\begin{array}{l}6739.2 \pm \\
1811.8\end{array}$ & $\begin{array}{c}566.8 \pm \\
19.8\end{array}$ & $\begin{array}{l}673.4 \pm \\
265.6\end{array}$ & $\begin{array}{c}6746.3 \pm \\
608.3\end{array}$ & $\begin{array}{c}388.6 \pm \\
67.0\end{array}$ & $\begin{array}{l}4894.1 \pm \\
488.2\end{array}$ & $\begin{array}{c}1075.1 \pm \\
184.7^{\ddagger}\end{array}$ & $\begin{array}{c}388.6 \pm \\
76.2\end{array}$ \\
\hline
\end{tabular}

*Values represent $\mathrm{m} \pm \mathrm{SEM}(n=4-8) .{ }^{\ddagger} P<0.05$ comparing control and $\mathrm{CD} 40 \mathrm{~L}-\mathrm{KO}$ mice. ${ }^{\S}$ Blood samples were obtained immediately before aerosol challenge. As indicated in Methods, challenge was carried out $12 \mathrm{~d}$ after sensitization. WBC, white blood cells; MO, monocytes; Ly, lymphocytes; Neu, neutrophils; Eos, eosinophils.

portant roles in regulating allergic inflammatory responses of the airways. IL-5 is likely the most important cytokine mediating eosinophilia (29-31). In addition to a critical role in $\operatorname{IgE}$ isotype switch, IL-4 as well as TNF $\alpha$ synergistically upregulates endothelial cell integrins required for the influx of inflammatory cells, particularly eosinophils and lymphocytes, into the tissue (32). Fig. 4 illustrates IL-5 levels in the serum and BAL of sensitized mice after antigen challenge. The time course of these changes is in agreement with our previous data, and it is apparent that CD40L-KO and control littermate mice generated a very substantial and similar IL-5 response. This finding is consistent with the observation that bone marrow eosinopoietic responses were similar in the mutant and control strains. To further examine IL-5 responses in CD40L-KO mice, we studied IL-5 production by spleen cell cultures in vitro. As shown in Table III, we detected similar amounts of IL-5 in the supernatant of spleen cells isolated from OVA-sensitized CD40L-KO and control littermates rechallenged in vitro with OVA. In contrast to IL-5, we found only marginal amounts of IL- 4 and TNF $\alpha$ in the BAL and, in the case of IL-4, in the serum after aerosol challenge of CD40L-KO mice compared with control mice (Figs. 5 and 6). Experiments with

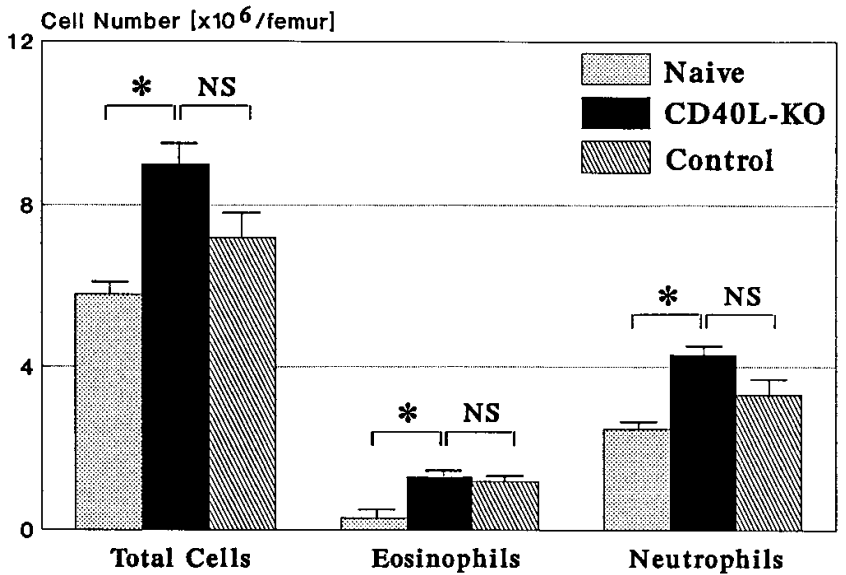

Figure 3. Cellular changes in the bone marrow of sensitized mice at day 3 after OVA aerosol challenge. Data represent mean $\pm \operatorname{SEM}(n=$ 6-8 per point). $* P \leq 0.05$ between naive and sensitized-challenged control littermate mice. No statistically significant differences were observed between CD40L-KO and control littermate mice. spleen cells isolated from OVA-sensitized mice show that cells isolated from CD40L-KO mice, upon rechallenge with OVA in vitro, yielded about a third the amount of IL-4 produced by cells isolated from control littermates.
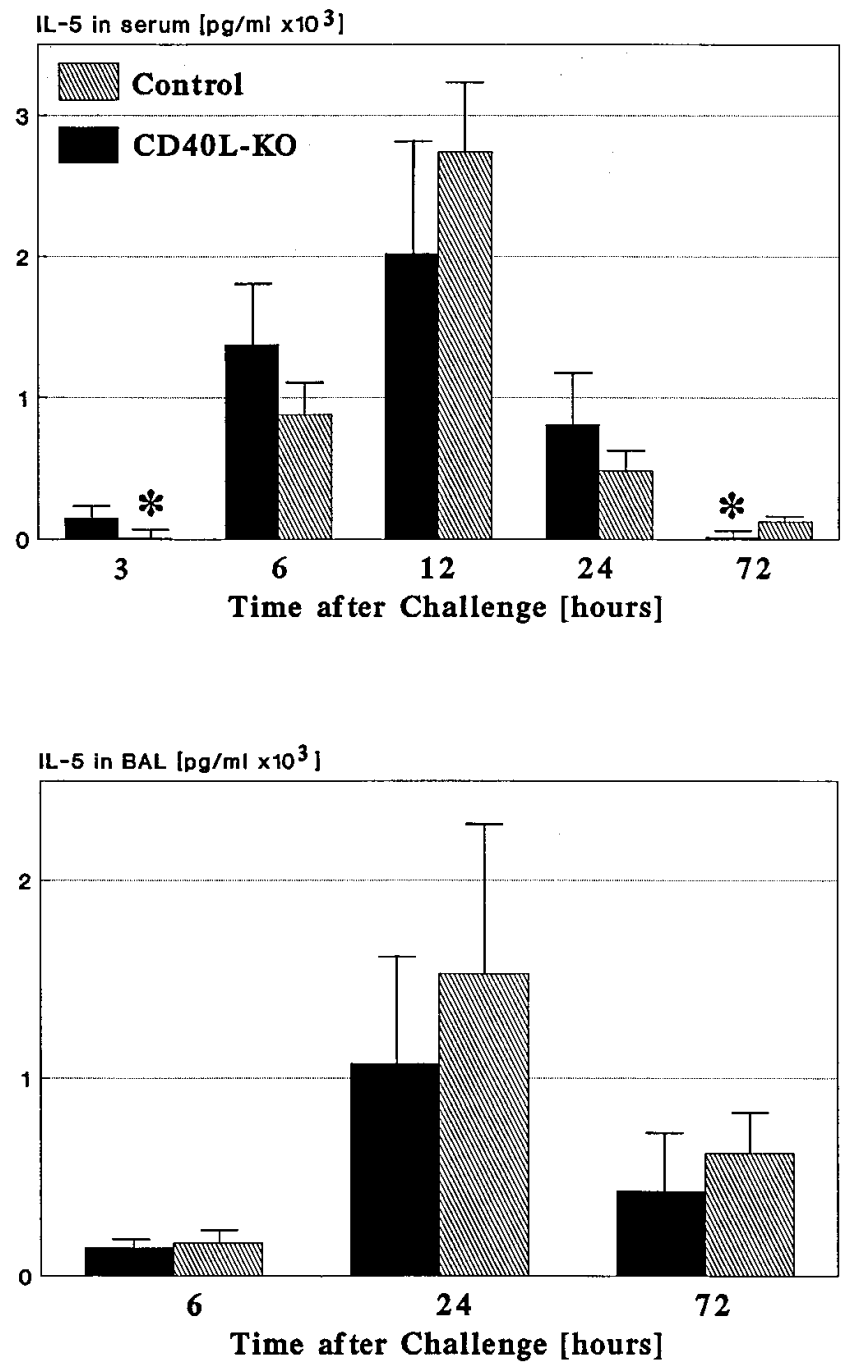

Figure 4. Levels of IL-5 in serum (top) and BAL (bottom) in sensitized mice after OVA aerosol challenge. Data represent mean \pm SEM ( $n=4-8$ per point). $* P \leq 0.05$ between CD40L-KO and control littermate mice. 
Table III. In Vitro Proliferation and Cytokine Responses in CD40L KO Mice

\begin{tabular}{|c|c|c|c|c|c|c|c|}
\hline \multirow[b]{2}{*}{ Sensitization } & \multirow[b]{2}{*}{ Recall } & \multicolumn{3}{|c|}{ Wild-type mice } & \multicolumn{3}{|c|}{ CD40L-KO mice } \\
\hline & & SI & IL-4 & IL-5 & SI & IL-4 & IL-5 \\
\hline & & & $p g / m l$ & $n g / m l$ & & $p g / m l$ & $n g / m l$ \\
\hline \multirow[t]{2}{*}{ Mock } & Medium & & 3 & 0 & & 1 & 0 \\
\hline & OVA & 1.3 & 0 & 0 & 1.5 & 0 & 0 \\
\hline \multirow[t]{2}{*}{ Mock } & Medium & & 0 & 0 & & 1 & 0 \\
\hline & OVA & 0.8 & 3 & 0 & 1.4 & 0 & 0 \\
\hline \multirow[t]{2}{*}{ OVA } & Medium & & 5 & 0 & & 0 & 0 \\
\hline & OVA & 3.1 & 413 & 19 & 4.5 & 139 & 15 \\
\hline \multirow[t]{2}{*}{ OVA } & Medium & & 5 & 1 & & 8 & 1 \\
\hline & OVA & 3.7 & 375 & 25 & 2.8 & 110 & 21 \\
\hline
\end{tabular}

Each individual value represents the average results of two mice. SI, stimulation index.
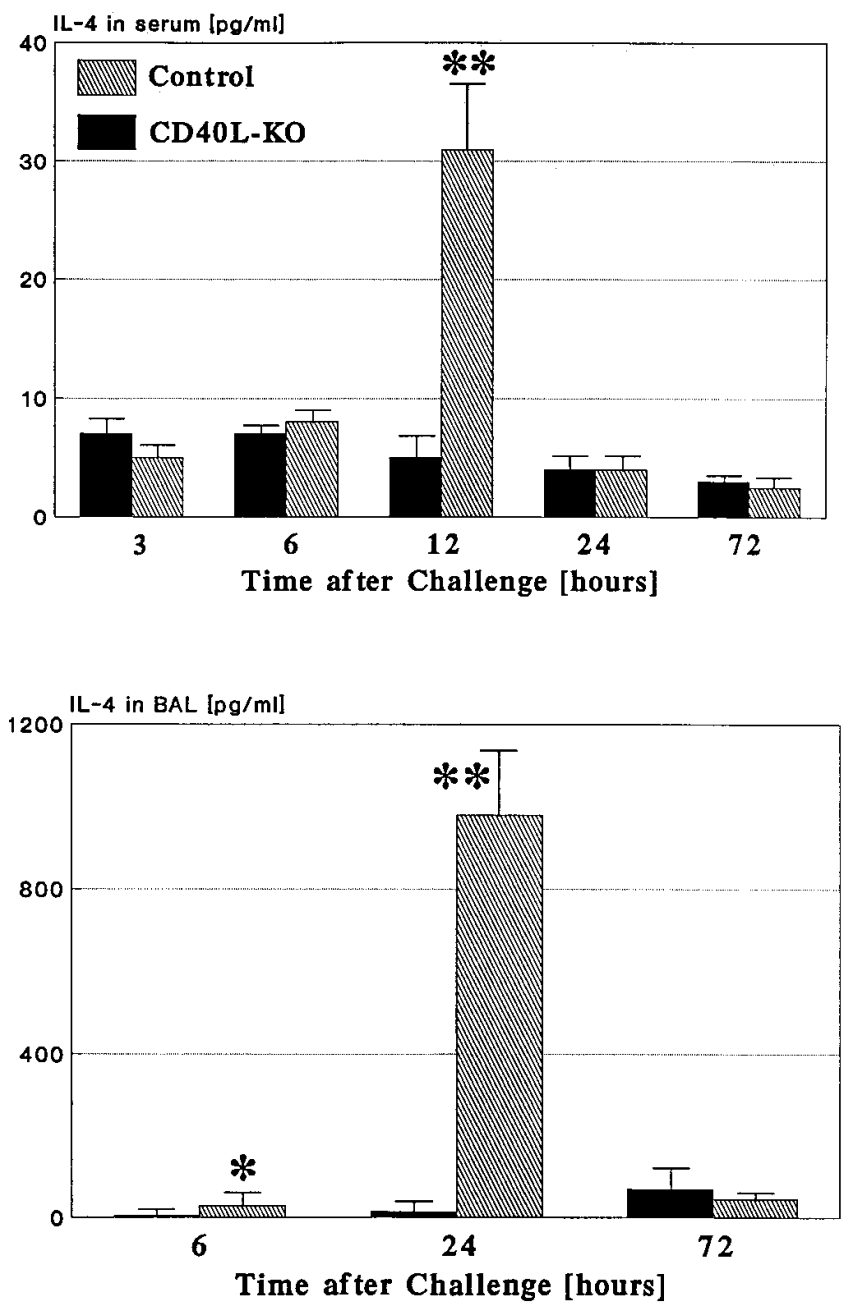

Figure 5. Levels of IL-4 in serum (top) and BAL (bottom) in sensitized mice after aerosol challenge. Data represent mean $\pm \operatorname{SEM}(n=$ 4-8 per point). $* P \leq 0.05$ and $* * P \leq 0.01$, respectively, between CD40L-KO and control littermate mice.

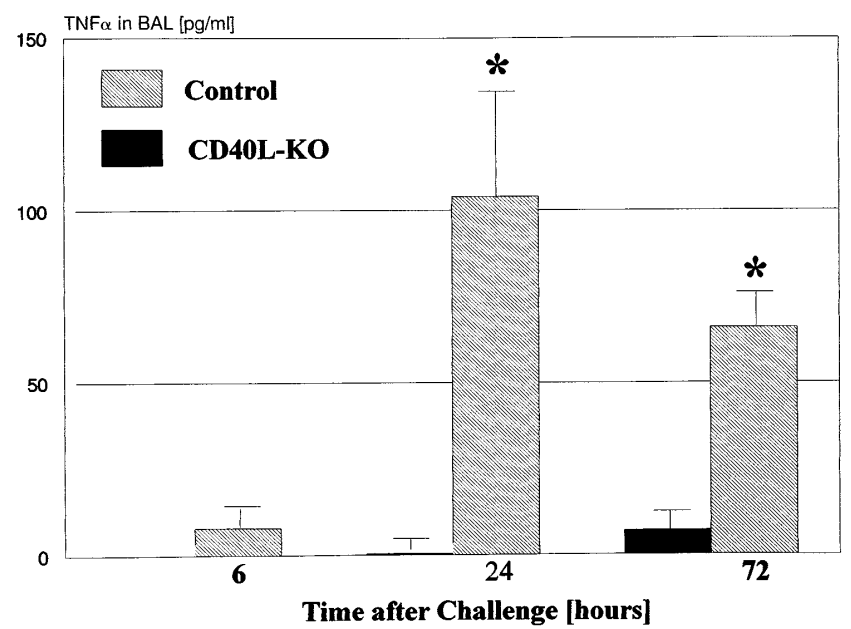

Figure 6. Levels of TNF $\alpha$ in the BAL in sensitized mice after aerosol challenge. Data represent mean $\pm \operatorname{SEM}(n=4-8$ per point $) . * P \leq 0.05$ between CD40L-KO and control littermate mice.

Endothelial expression of VCAM-1. That VCAM-1 is essential for eosinophil recruitment has been recently demonstrated in VCAM-1-deficient mice that fail to develop airways eosinophilia in response to OVA (25). Hence, we examined endothelial expression of VCAM-1 by immunohistochemistry. Using the semiquantitative evaluation method described above, VCAM-1 staining in naive control littermate mice as well as in mice sensitized with OVA and exposed to a control aerosol challenge with PBS was scored as grade 1 . In contrast, staining of OVA-sensitized and -challenged mice was scored as grade 3-4 at both 12 and $72 \mathrm{~h}$ after challenge. Staining of CD40LKO OVA-sensitized and aerosol-challenged mouse tissue was also scored as grade 1 (Fig. 7). Thus, endothelial expression of VCAM-1 in OVA-sensitized and -challenged CD40L-KO mice is remarkably reduced compared with that observed in control littermates.

Effect of IL-4 and TNF $\alpha$ overexpression on airways eosinophilia and VCAM-1 expression. Based upon these previous findings, we hypothesized that replacement of TNF $\alpha$, IL-4, or both in the tissue would upregulate VCAM-1 expression and reconstitute airways inflammation. Since recombinant cytokines have extremely short half-lives, we elected to use an adenoviral-mediated gene transfer approach with replicationdeficient adenovirus in order to achieve sustained levels of transgene in the airways. Our objective was to overexpress TNF $\alpha$ and IL-4 in the BAL of CD40L-KO mice at levels similar to those detected in OVA-sensitized and -challenged control littermates. Hence, we first performed dose-response and time-course studies for both $\mathrm{Ad} / \mathrm{TNF} \alpha$ and Ad/IL-4 administered intranasally (data not shown). Based on these initial experiments, we chose a dose of $1 \times 10^{7}$ pfu for both constructs, resulting in $\sim 400 \mathrm{pg} / \mathrm{ml}$ and $1,000 \mathrm{pg} / \mathrm{ml}$ of TNF $\alpha$ and IL-4, respectively, in the BAL at day 4 after intranasal administration of $\mathrm{Ad} / \mathrm{TNF} \alpha$ and $\mathrm{Ad} / \mathrm{IL}-4$. Fig. 8 shows the inflammatory cell content in the BAL of OVA-sensitized and -challenged CD40L-KO mice that received Ad/TNF $\alpha$ and Ad/IL-4 intranasally $4 \mathrm{~d}$ before challenge. Administration of either construct alone did not reconstitute airway inflammation. However, concurrent overexpression of TNF $\alpha$ and IL-4 fully 

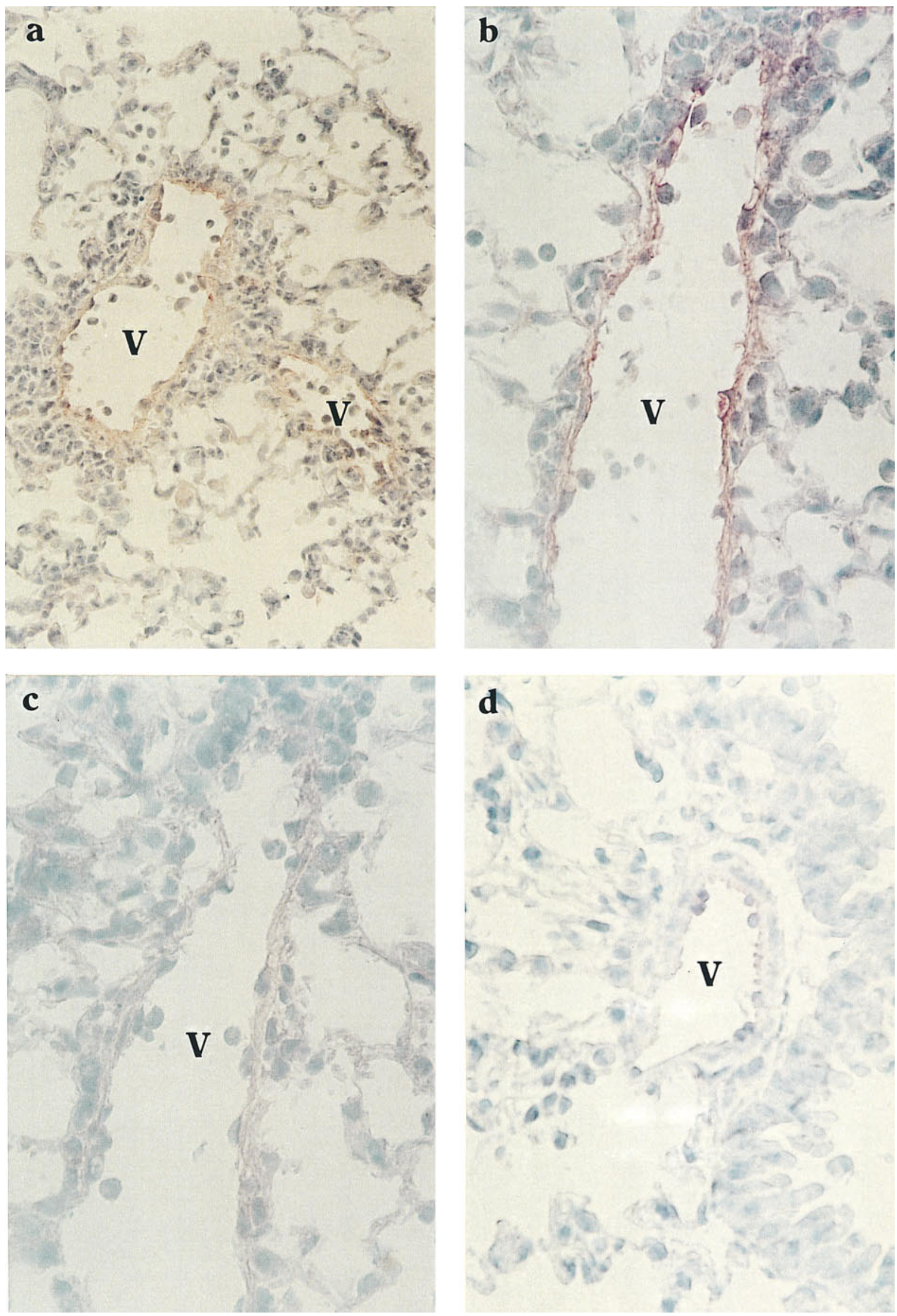

Figure 7. VCAM-1 immunostaining. Light photomicrograph of paraffin-embedded sections of lung tissues from OVA-sensitized and challenged control littermate $(a-c)$ and CD40L-KO $(d)$ mice obtained at day 3 after aerosol challenge. Tissues shown in $a, b$, and $d$ were stained with a monoclonal anti VCAM-1 antibody; tissue shown in $c$ was stained with a control anti $\operatorname{IgG}_{2}$ antibody. $V$, Vascular compartment. (a) 320×; $(b$ and $c$ ) $540 \times ;(d) 640 \times$. Note that intense endothelial reactivity $(r e d)$ is observed only in OVA-sensitized and -challenged control littermate mice $(a$ and $b$ ). 

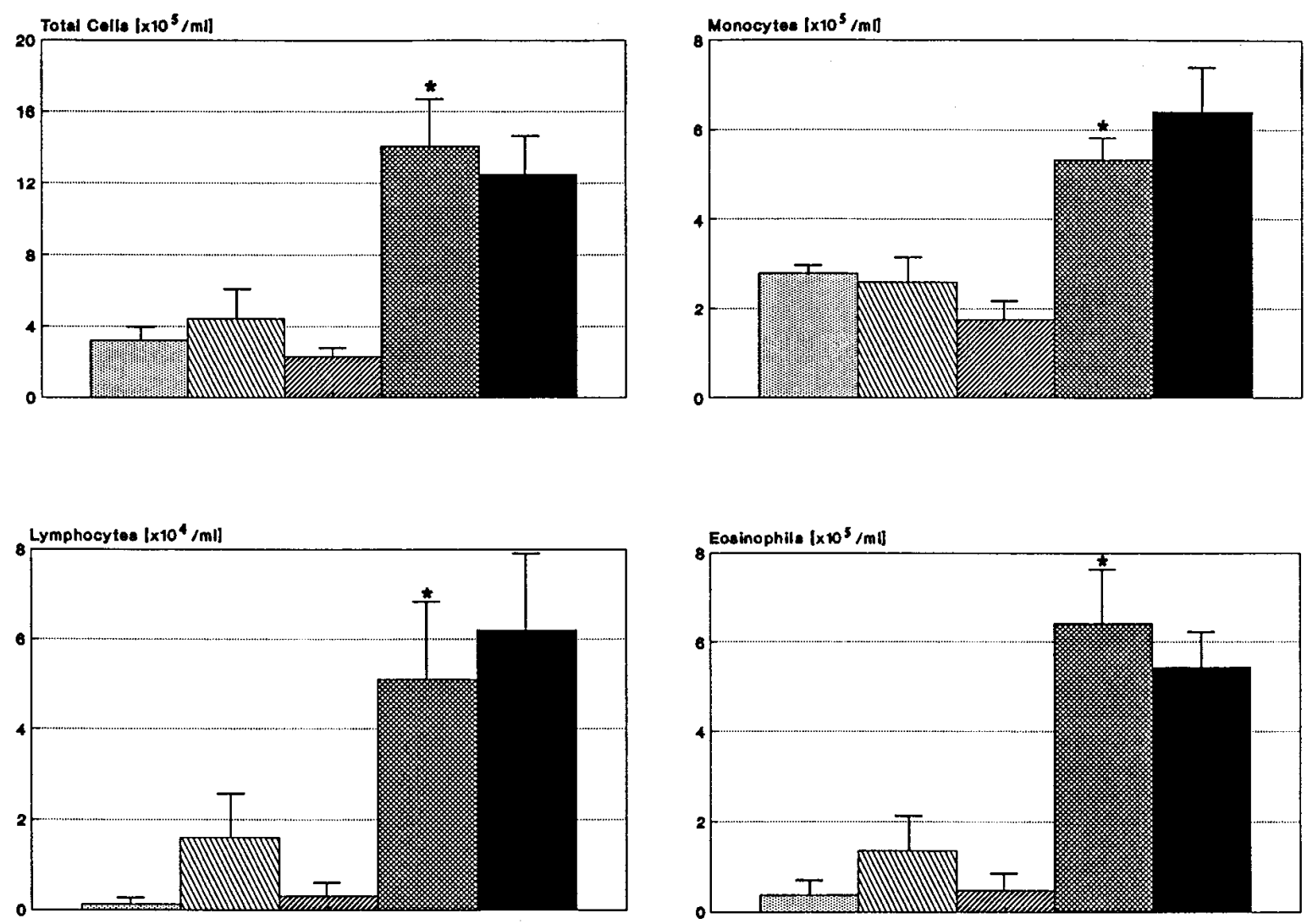

Figure 8. Cellular changes in the BAL of OVA-sensitized and -challenged mice. CD40L-KO mice were treated intranasally with control virus (dotted bar), or with Ad/IL-4 and Ad/TNF $\alpha$ alone (hatched bars, left to right), and together (double-hatched bars). The positive controls in these experiments were OVA-sensitized and -challenged control littermate mice (solid bar). Data represent mean \pm SEM ( $n=3-4$ per intervention). $* P \leq 0.05$ between interventions in CD40L-KO mice, i.e., Ad/IL-4 + Ad/TNF $\alpha$ vs. treatment with either construct alone or with control virus.

reconstituted airway eosinophilia, monocytosis, and lymphocytosis, while equivalent intranasal administration of control adenoviral vector did not induce significant airway inflammation. Histopathological assessment confirmed the BAL findings, as illustrated in Fig. 9. In addition, concurrent overexpression of $\mathrm{TNF} \alpha$ and IL-4, but not of either cytokine alone, upregulated endothelial cell expression of VCAM-1, which was semiquantitatively scored as grade 3 . Finally, only minimal airway inflammation was observed after administration of both $\mathrm{Ad} /$ $\mathrm{TNF} \alpha$ and $\mathrm{Ad} / \mathrm{IL}-4$ into nonsensitized, nonchallenged CD40L$\mathrm{KO}$ mice.

The role of the CD40-CD40L interaction in immune effector responses is a controversial issue under intense investigation. Oxenius et al. examined responses to viral antigens (lymphocytic choriomeningitis virus and vesicular stomatitis virus) in CD40- and CD40L-deficient mice, and demonstrated that $\mathrm{CD}^{+}{ }^{+} \mathrm{T}$ cells isolated from infected control and deficient mice secreted similar amounts of IL-2 and IFN $\gamma$ upon in vitro restimulation (33). However, Yang and Wilson have recently demonstrated that while $\mathrm{CD}^{+}{ }^{+} \mathrm{T}$ cells isolated from CD40Ldeficient mice infected in vivo with adenoviral vectors have increased basal levels of Th1 (IL-2 and IFN $\gamma$ ) and Th2 (IL-4 and IL-10) cytokines, these cells fail to respond to in vitro restimulation with viral antigens (34). We examined IL-5 because this is a cytokine critical for the eosinophilic response in both the bone marrow and the airways in our experimental model. Detection of IL-5 in very substantial amounts after antigen challenge in CD40L-KO mice in vivo and in spleen cells in vitro indicates that OVA-specific $\mathrm{T}$ cell activation and recall were not compromised in these mice under these experimental conditions.

The discrepancy between IL-5 vs. IL-4 and TNF $\alpha$ responses is of interest. A recent study investigating susceptibility to Leishmania amazonensis infection in CD40L-KO mice has demonstrated that these mice are not intrinsically deficient in their ability to produce IL-4 and TNFo in response to mitogens (19). Hence, the low levels of IL-4 and TNFa in CD40L$\mathrm{KO}$ mice that we observed both in vivo and in vitro suggests cellular sources other than lymphocytes. In this regard, Garlisi et al., using a similar model of OVA sensitization and challenge, have recently demonstrated that lung $\mathrm{T}$ cells are the main source of IL-5, but not of IL-4 mRNA expression after aerosol challenge (35). It is of course well-known that monocytes are important producers of TNF $\alpha$, and that mast cells can also produce $\mathrm{TNF} \alpha$ as well as IL-4 (36-38). Furthermore, there is evidence in human airway eosinophilic inflammation, asthma, and allergic rhinitis, that mast cells are an important source of IL-4 and TNF $\alpha$ immunoreactivity in the tissue (39, 40). Arguably, the lack of $\mathrm{IgE}$ and $\mathrm{IgG}_{1}$ in CD40L-KO mice would preclude arming of tissue cells bearing the receptor for 

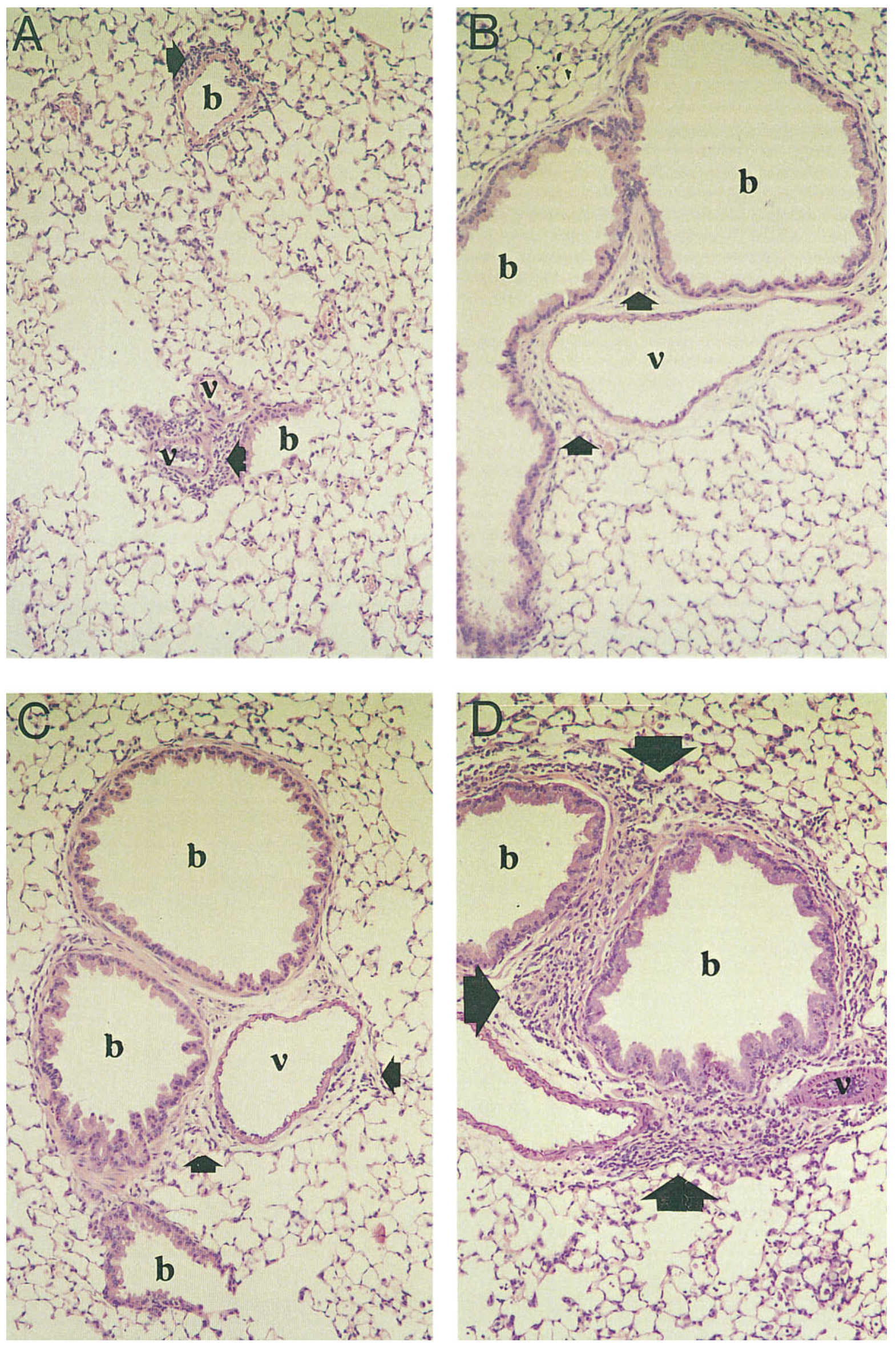

Figure 9. Light photomicrograph of paraffin-embedded sections of lung tissues stained with H\&E obtained from sensitized and challenged CD40L-KO mice at day 3 after OVA aerosol challenge. Before challenge, mice were treated intranasally with the following adenoviral constructs: $\mathrm{Ad} / \mathrm{control}(A), \mathrm{Ad} / \mathrm{TNF} \alpha(B), \mathrm{Ad} / \mathrm{IL}-4(C)$, and $\mathrm{Ad} / \mathrm{TNF} \alpha+\mathrm{Ad} / \mathrm{IL}-4(D) . v$, vascular compartment; $b$, bronchi. Arrows point at areas of inflammation which in $A-C$ are minimal. (A) $160 \times ;(B-D) 200 \times$. 
these immunoglobulins including monocyte/macrophages, mast cells, and eosinophils, and thus prevent subsequent cytokine production upon antigen exposure. However, our in vitro data showing that splenocytes from CD40L KO mice have a normal IL-5 response, but a markedly reduced IL-4 response may suggest different costimulatory requirements for induction of IL-4 and IL-5 in T cells.

Whatever the trigger for TNF $\alpha$ and IL-4 production in the airways, the importance of these cytokines to eosinophil recruitment was established by experimentation using a replication-deficient adenovirus to overexpress these cytokines locally. We used this approach because adenoviral vectors that result in relatively prolonged transgene expression are clearly superior instruments for gene transfer (41). The relatively low doses of $\mathrm{Ad} / \mathrm{TNF} \alpha$ and $\mathrm{Ad} / \mathrm{IL}-4$ that we used in CD40L-KO mice resulted in levels of transgene in the BAL that were reasonably similar to those detected in sensitized-challenged control littermates, bearing in mind that it is almost impossible to recapitulate these levels precisely with adenovectors. Under these conditions, the fact that either construct alone completely failed to upregulate VCAM-1 and to reconstitute airways inflammation was quite remarkable. In contrast, administration of both constructs resulted in full reconstitution of inflammatory events, representing an in vivo demonstration of the well-known synergistic effects of these two cytokines in in vitro systems.

In summary, this study confirms that CD40L-KO mice have a major defect in humoral responses, as manifested by undetectable levels of $\operatorname{IgE}$ and $\mathrm{IgG}_{1}$, and shows that they are unable to generate IL- 4 and TNF $\alpha$ responses after antigen challenge. We propose that these two events are related, supporting the notion that $\mathrm{IgE}$ - and/or $\mathrm{IgG}_{1}$-bearing cells are, upon antigen cross-linking, the main cellular source of these two cytokines in the airways. Our findings also demonstrate that CD40L-KO mice generate a vigorous IL-5 response upon antigen challenge, but this and the expected bone marrow eosinopoietic response are not sufficient to cause airway inflammation. Our data show that a disrupted CD40-CD40L interaction has a major impact on development of airways inflammation, likely the result of impaired recruitment of inflammatory cells into the tissue. We suggest that the CD40CD40 ligand interaction may be an important pharmacological target in regulating antigen-induced airway inflammatory responses.

\section{Acknowledgments}

We are thankful to Drs. Frank L. Graham and Jack Gauldie for providing the adenoviral constructs used in our experiments. The technical help of Susanna Goncharova and the secretarial assistance of Mary Kiriakopoulos are gratefully acknowledged.

This work was funded in part by the Ontario Thoracic Society and Astra Draco AB (Lund, Sweden). M.R. Stämpfli is holder of a Fellowship of the Medical Research Council/Canadian Lung Association, Z. Xing is holder of a Scholarship of the Medical Research Council, and M. Jordana is a Career Scientist of the Ontario Ministry of Health.

\section{References}

1. Bradley, B.L., M. Azzawi, M. Jacobson, B. Assoufi, J.V. Collins, A.M. Irani, L.B. Schwartz, S.R. Durham, P.K. Jeffery, and A.B. Kay. 1991. Eosinophils, T-lymphocytes, mast cells, neutrophils, and macrophages in bronchial bi- opsy specimens from atopic subjects with asthma: comparison with biopsy specimens from atopic subjects without asthma and normal control subjects and relationship to bronchial hyperresponsiveness. J. Allergy Clin. Immunol. 88: 661-674.

2. Corrigan, C.J., and A.B. Kay. 1992. T cells and eosinophils in the pathogenesis of asthma. Immunol. Today. 13:501-507.

3. Waserman, S., R. Olivenstein, P. Renzi, L.J. Xu, and J.G. Martin. 1992. The relationship between late asthmatic responses and antigen-specific immunoglobulin. J. Allergy Clin. Immunol. 90:661-669.

4. Robinson, D.S., Q. Hamid, S. Ying, A. Tricopoulos, J. Barkans, A.M. Bentley, C. Corrigan, S.R. Durham, and A.B. Kay. 1992. Predominant TH2-like bronchoalveolar T-lymphocyte population in atopic asthma. N. Engl. J. Med. 326:298-304.

5. Zweiman, B. 1993. The late-phase reaction: role of $\operatorname{IgE}$, its receptor and cytokines. Curr. Opin. Immunol. 5:950-955.

6. Ohkawara, Y., X.F. Lei, M.R. Stämpfli, J.S. Marshall, Z. Xing, and M. Jordana. 1997. Cytokine and eosinophil responses in the lung, peripheral blood and bone marrow compartments in a murine model of allergen-induced airways inflammation. Am. J. Respir. Cell Mol. Biol. 16:510-520.

7. Kung, T.T., H. Jones, G.K. Adams III, S.P. Umland, W. Kreutner, R.W. Egan, R.W. Chapman, and A.S. Watnick. 1994. Characterization of a murine model of allergic pulmonary inflammation. Int. Arch. Allergy Immunol. 105:83-90.

8 Kennedy, J.D., C.A. Hatfield, S.F. Fidler, G.E. Winterrowd, J.V. Haas, J.E. Chin, and I.M. Richards. 1995. Phenotypic characterization of T lymphocytes emigrating into lung tissue and the airway lumen after antigen inhalation in sensitized mice. Am. J. Respir. Cell Mol. Biol. 12:613-623.

9. Lack, G., A. Oshiba, K.L. Bradley, J.E. Loader, D. Amran, G.L. Larsen, and E.W. Gelfand. 1995. Transfer of immediate hypersensitivity and airway hyperresponsiveness by IgE-positive B cells. Am. J. Respir. Crit. Care Med. 152: 1765-1773.

10. Gavett, S.H., X. Chen, F. Finkelman, and M. Wills-Karp. 1994. Depletion of murine CD41 T lymphocytes prevents antigen-induced airway hyperreactivity and pulmonary eosinophilia. Am. J. Respir. Cell Mol. Biol. 10:587-593.

11. Banchereau, J., F. Bazan, D. Blanchard, F. Briere, J.P. Galizzi, C. van Kooten, Y.J. Liu, F. Rousset, and S. Saeland. 1994. The CD40 antigen and its ligand. Annu. Rev. Immunol. 12:881-922.

12. Jabara, H.H., S.M. Fu, R.S. Geha, and D. Vercelli. 1990. CD40 and IgE: synergism between anti-CD40 monoclonal antibody and interleukin 4 in the induction of IgE synthesis by highly purified human B cells. J. Exp. Med. 172: 1861-1864.

13. Grewal, I.S., and R.A. Flavell. 1996. A central role of CD40 ligand in the regulation of CD41 T-cell response. Immunol. Today. 17:410-414.

14. Hollenbaugh, D., H.D. Ochs, R.J. Noelle, J.A. Ledbetter, and A. Aruffo. 1994. The role of CD40 and its ligand in the regulation of the immune response. Immunol. Rev. 138:23-37.

15. Noelle, R.J., J.A. Ledbetter and A. Aruffo. 1992. CD40 and its ligand, and essential ligand-receptor pair for thymus-dependent c-cell activation. Immunol. Today. 13:431-433.

16. Ohkawara, Y., K.G. Lim, Z. Xing, M. Glibetic, K. Nakano, J. Dolovich, K. Croitoru, P.F. Weller, and M. Jordana. 1996. CD40 expression by human peripheral blood eosinophils. J. Clin. Invest. 97:1761-1766.

17. Kamanaka, M., P. Yu, T. Yasui, K. Yoshida, T. Kawabe, T. Horii, T. Kishimoto, and H. Kikutani. 1996. Protective role of CD40 in Leishmania major infection at two distinct phases of cell-mediated immunity. Immunity. 4:275-281.

18. Campbell, K.A., P.J. Ovendale, M.K. Kennedy, W.C. Fanslow, S.G. Reed, and C.R. Maliszewski. 1996. CD40 ligand is required for protective cellmediated immunity to Leishmania major. Immunity. 4:283-289.

19. Soong, L, J.C. Xu, I.S. Grewal, P. Kima, J. Sun, B.J. Longley, N.H. Ruddle, D. McMahon-Pratt, and R.A. Flavell. 1996. Disruption of CD40-CD40 ligand interactions results in an enhanced susceptibility to Leishmania amazonensis infection. Immunity. 4:263-273.

20. Snider, D.P., J.S. Marshall, M.H. Perdue, and H. Liang. 1994. Production of IgE antibody and allergic sensitization of intestinal and peripheral tissues after oral immunization with protein $\mathrm{Ag}$ and cholera toxin. J. Immunol. 153:647-657.

21. Addison, C.L., J. Gauldie, W.J. Muller, and F.L. Graham. 1995. An adenoviral vector expressing Interleukin-4 modulates tumorigenicity and induces regression in a murine breast cancer model. Int. J. Oncol. 7:1253-1260.

22. Marr, R.A., C.L. Addison, D. Snider, W.J. Muller, J. Gauldie, and F.L. Graham. 1997. Tumor immunotherapy using an adenoviral vector expressing a membrane bound mutant of murine TNF $\alpha$. Gene Ther. 4:1181-1188.

23. Bett, A.J., W. Haddara, L. Prevec, and F.L. Graham. 1994. An efficient and flexible system for construction of adenovirus with insertion of deletion in early regions 1 and 3. Proc. Natl. Acad. Sci. USA. 91:8802-8806.

24. Nonaka, M., R. Nonaka, K. Woolley, E. Adelroth, K. Miura, Y. Ohkawara, M. Glibetic, K. Nakano, P. O’Byrne, J. Dolovich, and M. Jordana. 1995. Distinct immunohistochemical localization of IL-4 in human inflamed airway tissues. J. Immunol. 155:3234-3244.

25. Gonzalo, J.A., C.M. Lloyd, L. Kremer, E. Finger, C. Martinez-A., M.H. Siegelman, M. Cybulsky, and J.C. Gutierrez-Ramos. 1996. Eosinophil recruitment to the lung in a murine model of allergic inflammation. The role of T cells, chemokines and adhesion receptors. J. Clin. Invest. 10:2332-2345. 
26. Renshaw, B., W.C. Fanslow, R.J. Armitage, K.A. Campbell, D. Liggit, B. Wright, B. Davison, and C.R. Maliszewski. 1994. Humoral immune responses in CD40 ligand-deficient mice. J. Exp. Med. 180:1889-1900.

27. Xu, J., T.M. Foy, J.D. Laman, E.A. Elliot, J.J. Dunn, T.J. Waldschmidt, J. Elsemore, R.J. Noelle, and R.A. Flavell. 1994. Mice deficient for the CD40 ligand. Immunity. 1:423-431.

28. Hogan, S.P., A. Mould, H. Kikutani, A.J. Ramsay, and P.S. Foster. 1997. Aeroallergen-induced eosinophilic inflammation, lung damage, and airways hyperreactivity in mice can occur independently of IL-4 and allergen-specific immunoglobulins. J. Clin. Invest. 99:1329-1339.

29. Foster, P., S.P. Hogan, A.J. Ramsay, K.I. Matthaei, and I.G. Young. 1996. Interleukin 5 deficiency abolishes eosinophilia, airway hyperreactivity, and lung damage in a mouse asthma model. J. Exp. Med. 183:195-201.

30. Kung, T.T., D.M. Stelts, J.A. Zurcher, G.K. Adams III, R.W. Egan, W. Kreutner, A.S. Watnick, H. Jones, and R.W. Chapman. 1995. Involvement of IL-5 in a murine model of allergic pulmonary inflammation: prophylactic and therapeutic effect of an anti-IL-5 antibody. Am. J. Respir. Cell. Mol. Biol. 13: $360-365$.

31. Nakajima, H., I. Iwamoto, S. Tomoe, R. Matsumura, H. Tomioka, K. Takatsu, and S. Yoshida. 1992. CD41 T-lymphocytes and interleukin-5 mediate antigen-induced eosinophil infiltration into the mouse trachea. Am. Rev. Respir. Dis. 146:374-377.

32. Ledemarco, M.F., J.L. Barks, and D.C. Dean. 1995. Regulation of vascular cell adhesion molecule-1 expression by IL-4 and TNF $\alpha$ in cultured endothelial cells. J. Clin. Invest. 95:264-271.

33. Oxenius, A., K.A. Campbell, C.R. Maliszewski, T. Kishimoto, H. Kikutani, H. Hengartner, R.M. Zinkernagel, and M.F. Bachmann. 1996. CD40-
CD40 ligand interactions are critical in T-B cooperation but not other anti-viral CD41 T cell functions. J. Exp. Med. 183:2209-2218.

34. Yang, Y., and J.M. Wilson. 1996. CD40 ligand-dependent T cell activation: requirement of B7-CD28 signaling through CD40. Science. 273:1862-1864.

35. Garlisi, C.G., A. Falcone, M.M. Billah, R.W. Egan, and S.P. Umland 1996. T cells are the predominant source of interleukin-5 but not interleukin-4 mRNA expression in the lungs of antigen-challenged mice. Am. J. Respir. Cell. Mol. Biol. 15:420-427.

36 Gordon, J.R. and S.J. Galli. 1990. Mast cells as a source of both preformed and immunologically inducible TNF $\alpha /$ Cachectin. Nature. 346:274-276.

37. Brown, M.A., J.H. Pierce, C.J. Watson, J. Falco, J.N. Ihle, and W.E. Paul. 1987. B cell stimulatory factor-/interleukin-4 mRNA is expressed by normal and transformed mast cells. Cell. 50:809-818.

38. Bradding, P., P.H. Feather, R. Howarth, J.A. Mueller, K. Roberts, J.P.A. Britten, T.C. Bews, Y. Hunt, C.H. Okayama, et al. 1992. Interleukin 4 is localized to and released by human mast cells. J. Exp. Med. 176:1381-1389.

39. Bradding, P., J.A. Roberts, K.M. Britten, S. Montefort, R. Djukanovic, R. Mueller, C.H. Heusser, P.H. Howarth, and S.T. Holgate. 1994. Interleukin-4, -5 , and tumor necrosis factor- $\alpha$ in normal and asthmatic airways: evidence for the human mast cell as a source of these cytokines. Am. J. Respir. Cell Mol. Biol. 10:471-480.

40. Bradding, P., R. Mediwake, I.H. Feather, J. Madden, M.K. Church, S.T Holgate, and P.H. Howarth. 1995. TNF $\alpha$ is localized to nasal mucosal mast cells and is released in acute allergic rhinitis. Clin. Exp. Allergy. 25:406-415.

41. Kozarsky, K.F., and J.M. Wilson. 1993. Gene therapy: adenovirus vectors. Curr. Opin. Genet. Dev. 3:499-503. 